\title{
DESCRIPTION AND ANALYSIS OF A 20-YEAR (1960-79)

\author{
DIGITAL ICE-CONCENTRATION DATABASE FOR THE
}

\author{
GREAT LAKES OF NORTH AMERICA*
}

\author{
by
}

\author{
Raymond A. Assel \\ (National Oceanic and Atmospheric Administration, Great Lakes Environmental Research \\ Laboratory, 2300 Washtenaw Avenue, Ann Arbor, Michigan 48104, U.S.A.)
}

\section{ABSTRACT}

A digital ice-concentration database spanning 20 years (1960 to 1979) was established for the Great Lakes of North America. Data on ice concentration, i.e. the percentage of a unit surface area of the lake that is ice-covered, were abstracted from over 2800 historic ice charts produced by United States and Canadian government agencies. The database consists of ice concentrations ranging from zero to $100 \%$ in $10 \%$ increments for individual grid cells of size $5 \times 5 \mathrm{~km}$ constituting the surface area of each Great Lake. The data set for each of the Great Lakes was divided into half-month periods for statistical analysis. Maximum, minimum, median, mode, and average ice-concentrations statistics were calculated for each grid cell and half-month period. A lakewide average value was then calculated for each of the half-month ice-concentration statistics for all grid cells for a given lake. Ice-cover variability and the normal extent and progression of the ice cover is discussed within the context of the lakewide averaged value of the minimum and maximum ice concentrations and the lakewide averaged value of the median ice concentrations, respectively. Differences in ice-cover variability among the five Great Lakes are related to mean lake depth and accumulated freezing degree-days. A Great Lakes ice atlas presenting a series of ice charts which depict the maximum, minimum, and median icecover concentrations for each of the Great Lakes for nine half-monthly periods, starting the last half of December and continuing through the last half of April will be published in 1933 by the National Oceanic and Atmospheric Administration (NOAA). The database will be archived at the National Snow and Ice Data Center of the National Environmental Satellite Data and Information Service (NESDIS) in Boulder, Colorado, USA, also in 1983.

\section{INTRODUCTION}

The Laurentian Great Lakes, shown in Figure 1, are one of the major water resources of North America. Systematic observations of the ice cover of the Great Lakes have been made for over 20 years by United States and Canadian government agencies in support of activities in the fields of research, operations,

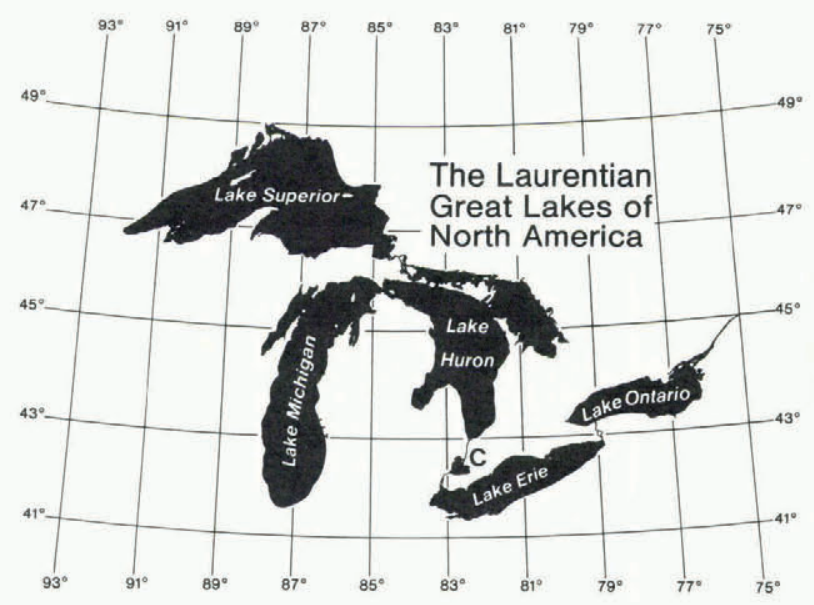

Fig.1. Map showing the relative positions of the Great Lakes and Lake St Clair (C).

and planning. The ice cover is important because it has a major impact on the economy of the Great Lakes region through its effects on navigation, hydropower generation, lake levels, flooding, and damage to shore structures. Reports describing the annual ice cycle for individual winters have been published during the past 20 years and many of them are included in the selected bibliography for this paper.

An initial analysis of the ice-cover data was made by Rondy (1969). He produced an ice atlas of normal ice cover on the Great Lakes for early winter. midwinter, and for the periods of maximum ice extent and early ice decay based on a subjective analysis of data from six winters. The Great Lakes-St Lawrence Seaway Winter Navigation Demonstration Program, authorized by the United States Congress in 1970 and completed in 1979, provided the major impetus to revise Rondy's ice atlas because of the need for greater detail in ice-cover data to support increasing operational and research activities.

This paper describes a database containing

* Great Lakes Environmental Research Laboratory (GLERL) Contribution No.314. 
information spanning a period of 20 years which was established for the revision of Rondy's atlas and highlights results of a statistical analysis with respect to the extremes, variability, and normal progression of ice cover on the Great Lakes. A detailed description of the statistical analysis, will be given in a forthcoming ice atlas to be published by NOAA. The database will be archived at the National Snow and Ice Data Center of the National Environmental Satellite Data and Information Service (NESUIS) in Boulder, Colorado, USA.

\section{DESCRIPTION OF THE DATABASE}

Ice charts of the Great Lakes for the 20-year period from 1960 to 1979 have been produced by the organizations listed in Table I. The ice charts have

TABLE I. SOURCES OF HISTORIC ICE CHARTS OF THE GREAT LAKES

\section{Source}

Organization
1
Environment Canada, Atmospheric Environment Service, Ice Branch, Ottawa, Untario $\mathrm{K} 1 \mathrm{~A} \mathrm{OH} 3$, Canada.

Great Lakes Environmental Research Laboratory, 2300 Washtenaw Avenue, Ann Arbor, Michigan 48104, USA. (This data set includes ice charts from the Lake Survey Center, National Ocean Survey, and the Lake Survey District, US Army Corps of Engineers, Detroit, Michigan 48226 , USA.)*

US Coast Guard, Ninth Coast Guard District, 1240 East Ninth Street, Cleveland, Ohio 44199, USA.

appeared in several different map projections, at different scales, using different ice-cover symbols and terminologies. Uver 2800 historic ice charts were digitized for this study, reducing the abstracted data to a common polyconic map projection, as well as a common ice-concentration code. Information

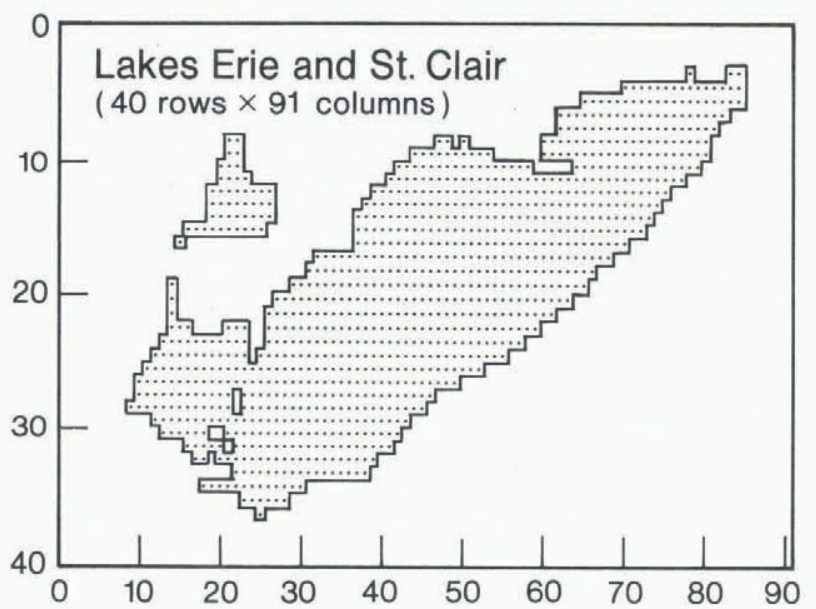

Fig.2. Configuration and location of the 1041 overwater grid cells, indicated by dots (.) in the $40 \times 91$ digital data matrix of Lake Erie and Lake St Clair. relating to ice concentration (the percentage of a unit surface area of the lake that is ice-covered) was abstracted from the original ice charts to the nearest $10 \%$ from a range of zero to $100 \%$ ice cover. An electronic digitizer coupled with a computer was used to abstract, code, and record the ice concentrations from individual ice charts. The digital data were then converted to $5 \times 5 \mathrm{~km}$ grid cells in a rectangular Cartesian coordinate system having a polyconic map projection. An example of the configuration of overwater grid cells for Lake Erie and Lake St Clair is given in Figure 2. The matrix dimensions for each Great Lake and the number of ice charts digitized are given in Table II.

TABLE II. ICE-CONCENTRATION DATABASE FOR THE GREAT LAKES (1960 to 1979).

Lake $\quad \begin{array}{ll}\text { Number of } \\ \text { ice charts }\end{array} \quad \begin{aligned} & \text { Number of grid cells } \\ & \text { dimension** }\end{aligned}$

$\begin{array}{lrrrr}\text { Superior } & 618 & 71 \times 121 & 3 & 195 \\ \text { Michigan } & 489 & 117 \times 77 & 2224 \\ \text { Huron } & 845 & 85 \times 95 & 2 & 308 \\ \text { Erie and St Clair } & 565 & 40 \times 91 & 1041 \\ \text { Untario } & 307 & 34 \times 73 & 739\end{array}$

METHODS OF ANALYSIS

The ice-concentration data set for each Great Lake was partitioned into half-month intervals for statistical analysis. This interval was chosen because it is the smallest averaging period for which there are sufficient data for analysis. Each half-month period was coded as follows:

\begin{tabular}{|c|c|}
\hline $16-31$ & December \\
\hline $1-15$ & January \\
\hline $16-31$ & January \\
\hline $1-14$ & February \\
\hline $15-28$ & February \\
\hline $1-15$ & March \\
\hline $16-31$ & March \\
\hline $1-15$ & April \\
\hline $16-30$ & April \\
\hline
\end{tabular}

The number of charts for each half-month period is given in Table III. The time series of ice concentrations for each grid cell for a given period was

TABLE III. NUMBER OF ICE CHARTS USED FOR THE STATISTICAL ANALYSIS OF ICE CONCENTRATION FOR EACH GREAT LAKE FOR EACH OF THE NINE HALF-MONTH PERIODS OVER THE 20-YEAR PERIOD 1960-79 (for period codes, see above)

$\begin{array}{lrrrrrrrrr}\text { Lake } & \text { D2 } & \text { J1 } & \text { J2 } & \text { F1 } & \text { F2 } & \text { M1 } & \text { M2 } & \text { A1 } & \text { A2 } \\ \text { Superior } & 33 & 43 & 88 & 82 & 65 & 83 & 93 & 87 & 44 \\ \text { Michigan } & 25 & 35 & 67 & 70 & 59 & 79 & 75 & 63 & 16 \\ \text { Huron } & 36 & 64 & 124 & 116 & 111 & 134 & 133 & 94 & 33 \\ \text { Erie \& St C1air } & 28 & 50 & 86 & 76 & 81 & 87 & 77 & 61 & 19 \\ \text { Ontario } & 16 & 26 & 52 & 38 & 40 & 41 & 39 & 42 & 13\end{array}$

analyzed for minimum and maximum ice concentrations. Subperiod ice concentrations for a given cell for which there were multiple observations for a given year were averaged; then the average, median, and mode ice concentrations were calculated for the resultant time series at each grid cell. A lakewide average value was then calculated for each half-

*The Lake Survey Center and the Lake Survey District were dissolved in the 1970 s.

$\star *$ Row and column dimension of total number of grid cells includes land area portions of the data matrix

for each ice chart. 

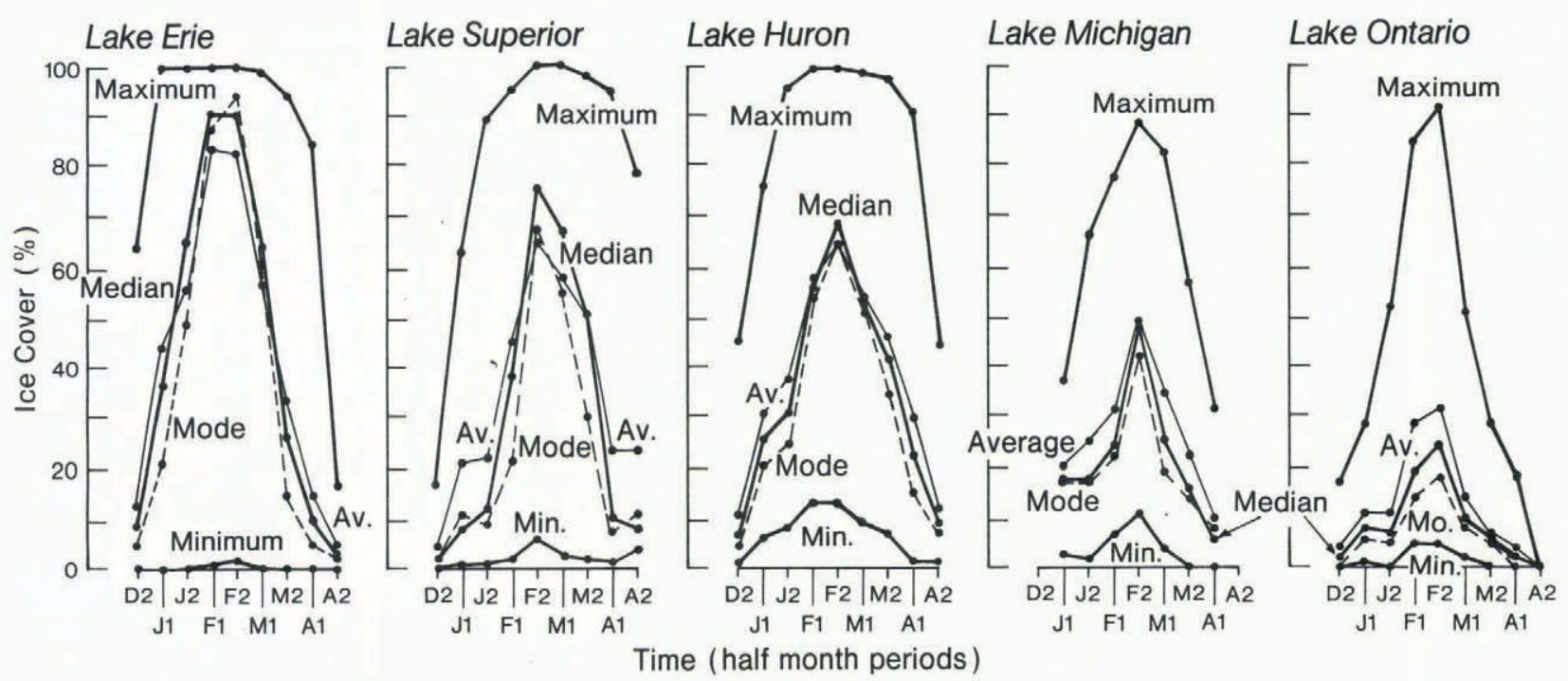

Fig.3. Lakewide average value for each half-month ice-concentration statistic (maximum, minimum, average, mode, and median) for the nine half-month periods starting with the last half of December (D2) and continuing through the last half of April (A2) for each of the Great Lakes. For period codes, see page 15.

month ice-concentration statistic by averaging all grid cells. The lakewide average is used to indicate the lakewide trend of each statistic over the nine half-monthly periods and for making comparisons with other lakes.

\section{DISCUSSION OF RESULTS}

Lakewide averaged values of the maximum, minimum, average, median, and mode ice concentration are shown in Figure 3. The maximum and minimum curves illustrate the extremes in ice cover, while the median, mode, and average are used to estimate "normal" ice concentrations. Ice charts depicting patterns of icecover distribution for the maximum, minimum, and median ice concentrations over the nine half-monthly periods will be presented in the NOAA ice atlas scheduled for publication in 1983.

\section{ICE-COVER VARIABILITY}

The difference between lakewide averaged maximum and minimum ice concentrations is a measure of the variability of the ice cover over the period of record for each half-monthly period. As shown on Table IV and portrayed in Figure 3 , the ice-cover variability for the nine half-monthly periods is largest for Lake Erie, followed in order by Superior, Huron, Michigan, and Ontario. The ice-cover variability for each half-monthly period averaged over the five Great Lakes is also given in Table IV. As might be expected, ice-cover variability is smallest during the period of initial ice formation and the period

TABLE IV. VARIATION OF ICE CONCENTRATION (LAKEWIDE AVERAGE OF HALF-MONTHLY MAXIMUM MINUS LAKEWIDE AVERAGE OF HALF-MONTHLY MINIMUM) EXPRESSED AS A PERCENTAGE FOR EACH LAKE FOR THE 20-YEAR PERIOD FROM 1960 to 1979 (for period codes, see page 15)

\begin{tabular}{llrrrrrrrr} 
& \multicolumn{10}{c}{ Half-month period } \\
Lake & D2 & J1 & J2 & F1 & F2 & M1 & M2 & A1 & A2 \\
& & & & & & & & & \\
Superior & 17 & 62 & 88 & 93 & 93 & 97 & 96 & 94 & 74 \\
Michigan & $\star \star$ & 34 & 64 & 70 & 77 & 78 & 57 & 31 & $\star *$ \\
Huron & 45 & 69 & 87 & 86 & 86 & 89 & 90 & 89 & 43 \\
Erie & 64 & 100 & 100 & 99 & 98 & 99 & 94 & 84 & 17 \\
Ontario & 17 & 27 & 52 & 79 & 86 & 49 & 28 & 18 & 0 \\
Average* & 36 & 58 & 78 & 85 & 88 & 82 & 73 & 63 & 34
\end{tabular}

* average over all lakes for one period

** insufficient data of final ice loss, when it averages approximately $35 \%$ for the five lakes. At its maximum, during the last half of February, ice-cover variability averages $38 \%$. The latter half of February is the half-month when ice cover is normally at its greatest areal extent, so that the greatest difference in ice cover over the 20 winters should logically occur during this halfmonth period. Ice-cover variability over the nine half-monthly periods for individual lakes is indirectly related to mean lake depth, which is the ratio of the volume to the surface area, and is directly related to cumulative freezing degree-days (FDDs), which is a measure of the cumulative departure of the mean daily air temperature from $0^{\circ} \mathrm{C}$ over the winter season. Mean values of ice-cover variation, lake depth, and FDDs are given in Table V.

Lake Erie and Lake Huron, with mean depths of 19 and $59 \mathrm{~m}$ respectively, have less heat to lose before ice forms than have the other Great Lakes and so can develop more extensive ice covers early in the season than can the other Great Lakes. Thus, in early winter the ice-cover variation is greater for these two lakes compared to the other lakes. Ice-cover variabilranges from $64 \%$ on Lake Erie to $17 \%$ on Lake Ontario during the second half of December.

Ice-cover variability for February and the first half of March averages over 80\% for the Great Lakes and is related to FDD accumulation; for more detail, see studies by Richards (1964) and Rogers (1976). In most years, above-freezing air temperatures (i.e. negative FDDs) in early March bring a reduction in ice cover. This is reflected in decreasing ice-cover

TABLE V. MEAN LAKE DEPTH, FREEZING DEGREE-DAYS (FDDS) AND AVERAGED ICE-COVER VARIABILITY

\begin{tabular}{lcrrr} 
Lake & $\begin{array}{c}\text { Ice-cover } \\
\text { variability* }\end{array}$ & $\begin{array}{c}\text { Mean lake } \\
\text { depth }(\mathrm{m})\end{array}$ & $\begin{array}{c}\mathrm{FDDS}^{* *}\left({ }^{\circ} \mathrm{C}\right) \\
(\text { mean) }\end{array}$ & SD*** \\
Erie & 84 & 19 & 326 & 143 \\
Superior & 79 & 149 & 1100 & 201 \\
Huron & 76 & 59 & 611 & 169 \\
Michigan & 59 & 85 & 563 & 167 \\
Ontario & 40 & 86 & 461 & 152 \\
\hline
\end{tabular}

* Average value for the nine half-monthly periods.

$\star \star$ An average for 80 winters (1898 to 1977) of annual maximum FDDs for selected stations on the perimeter of each lake.

$\star \star \star$ Standard deviation of FDDs. 
variability, first on Lake Ontario during the first half of March, next on Lake Michigan during the second half of March, and finally on the remaining lakes during April. In the case of Lake Erie and Lake Huron, high ice-cover variability occurs up to midApril, while in the case of Lake Superior, and the northern sections of Lake Michigan and Lake Huron low air temperatures can preserve existing ice covers into May during some years, resulting in high icecover variability through the second half of April.

\section{NORMAL ICE COVER}

In general, ice covers are restricted to the bays, harbors, and constricted areas of the Great Lakes through the end of January, with the exception of Lake Erie, where ice covers form in mid-lake in January owing to the shallow water. Ice forms in the mid-lake areas of the Great Lakes in February and ice cover reaches its maximum areal extent in this month or early March. During the time of maximum ice extent, the median ice concentration on the Great Lakes is: Erie $90 \%$, Superior $75 \%$, Huron $68 \%$, Michigan $45 \%$, and Ontario $24 \%$.

Ice covers begin to decline in extent in March. The largest decrease in ice cover for Lakes Michigan and Ontario occurs during the first half of March. The largest decrease in ice cover for Lake Erie occurs during the second half of March, although Lake Erie also has a significant decrease in ice cover during the first half of March. The greatest loss in ice cover for Lakes Superior and Huron occurs during the first half of April. By the second half of April, less than $10 \%$ of the surface area of the Great Lakes is normally ice-covered. The remaining ice is usually located in bays, harbors, along windward shores, and in constricted areas.

\section{CONCLUDING REMARKS}

A 20-year computerized ice-concentration database has been established for the Great Lakes and used for a statistical analysis of the ice cover for nine half-monthly periods. Lakewide trends for maximum, minimum, median, mode, and average ice-concentration statistics over the nine half-monthly periods have been identified. Ice-cover variation is defined by the difference between lakewide average maximum and minimum ice concentrations for individual lakes. The median, inode, and average statistics were used to estimate the normal extent of ice cover.

Ice charts depicting the maximum, minimum, and median ice cover for the nine half-month periods will be published as a NOAA ice atlas. The entire digital ice-concentration data set will be transferred to the National Snow and Ice Data Center, INESDIS, Boulder, Colorado, USA and documented by a report describing its format and structure. It is hoped that these data will prove useful to a broad spectrum of users in the fields of research, operations, and planning. Further analysis of the data will include spatial and temporal correlations of the ice concentration, as well as examination of the relationship of ice concentration with lake depth and air temperatures on sub-lake spatial scales.

\section{REFERENCES}

Richards T L 1964 The meteorological aspects of ice cover on the Great Lakes. Monthly Weather Review 92(6): 292-302

Rogers J C 1976 Long-range forecasting of maximum ice extent on the Great Lakes. NOAA Technicat Memorandum ERL GLERL-7

Rondy D R 1969 Great Lakes ice atlas. US Army. Lake Survey District. Corps of Engineers. Research Report RR 5-6
SELECTED BIBLIOGRAPHY

Assel R A 1972[a] Great Lakes ice cover, winter 1970-71. NOAA Technical Memorandum NOS' LSCD 4

Assel R A 1972[b] Great Lakes ice cover, winter 1971-72. NOAA Technical Memorandum NOS LSCD 6

Assel R A 1974[a] Great Lakes ice cover, winter 1972-73. NOAA Technical Memorandum NOS LSCD 7

Assel R A 1974[b] Great Lakes ice cover, winter 1973-74. NOAA Technical Report ERL 325-GLERL-1

Assel R A, Boyce D E, DeWitt B H, Wartha J, Keyes F A 1979 Summary of Great Lakes weather and ice conditions, winter 1977-78. NOAA Technical Memorandum ERL GLERL-26

Canada. Department of Transport. Meteorological Branch 1960 Aerial ice observing and reconnaissance - the Great Lakes. Toronto, Ontario. Department of Transport (Technical Circular 3361, TEC 328)

Canada. Department of Transport. Meteorological Branch 1961 Aemial ice observing and reconnaissance - the Great Lakes. Toronto, Ontario. Department of Transport (Technical Circular 3350, TEC 371)

Canada. Department of Transport. Meteorological Branch 1962 Aerial ice observing and reconnaissance - the Great Lakes. Toronto, Ontario. Department of Transport (Technical Circular 3772, TEC 440)

Canada. Department of Transport. Meteorological Branch 1963 Aerial ice observing and reconnaissance - the Great Lakes. Toronto, Dntario. Department of Transport (Technical Circular 3987, ICE 13)

Canada. Department of Transport. Meteorological Branch 1964 Ice observations - Canadian intand watemays. Toronto, Ontario. Department of Transport

Canada, Department of Transport. Meteorological Branch 1965 Ice observations - Canadian inland watemways. Toronto, Ontario. Department of Transport

Canada. Department of Transport. Meteorological Branch 1966 Ice observations - Canadian inland watemways. Toronto, Dntario. Department of Transport

Canada. Department of Transport. Meteorological Branch 1967 Ice observations - Canadian inland watemways. Toronto, Ontario. Department of Transport

Canada. Department of Transport. Meteorological Branch 1968 Ice observations - Canadian inland waterways. Toronto, Ontario. Department of Transport

Canada. Department of Transport. Meteorological Branch 1969 Ice observations - Canadian inland watemways. Toronto, Ontario. Department of Transport

Canada. Department of Transport. Meteorological Branch 1970 Ice observations - Canadian inland watemways. Toronto, Ontario. Department of Transport

Canada. Department of Transport. Meteorological Branch 1971 Ice observations - Canadian inland waterways. Toronto, Ontario. Department of Transport

Canada. Department of Transport. Meteorological Branch 1975 Ice thickness summary for selected Canadian stations; means, extremes, and standard deviations of ice thickness and snow depth on ice. Toronto, Ontario, Department of Transport (Technical Circular ICE 1-75)

Dewitt B H and 9 others 1980 Summary of Great Lakes weather and ice conditions, winter 1978-79. NOAA Technical Memorandum ERL GLERL-31

Leshkevich G A 1976 Great Lakes ice cover, winter 1974-75. NOAA Technical Report ERL 370-GLERL 11

Leshkevich G A 1977 Great Lakes ice cover, winter 1975-76. NOAA Technical Memorandum ERL GLERL-12

Quinn $F H$, Assel $R A$, Boyce $D E$, Leshkevich $G A$, Snider C R, Weisnet D 1978 Summary of Great Lakes weather and ice conditions, winter 1976-77. NOAA Technical Memorandum ERL GLERL-20

Rondy D R 1966 Great Lakes ice cover, winter 1965-66. US Army. Lake Survey District. Corps of Engineers. Basic Data Report BDR 5-2

Rondy D R 1967 Great Lakes ice cover, winter 1966-67. US Army. Lake Survey District. Corps of Engineers. Basic Data Report BDR 5-3

Rondy D R 1968 Great Lakes ice cover, winter 1967-68. US Army. Lake Survey District. Corps of Engineers. Basic Data Report BDR 5-4 
Assel: Ice-concentration database for the Great Lakes

Rondy D R 1969 Great Lakes ice cover, winters

1962-63 and 1963-64. US Army. Lake Survey

District. Corps of Engineers. Basic Data Report BDR 5-5

Rondy D R 1971 Great Lakes ice cover, winter

1968-69. NOAA Technical Memorandum NOS LSCD 1

Rondy D R 1972 Great Lakes ice cover, winter

1969-70. NOAA Technical Memorandum NOS LSCD 3

Wilshaw R E, Rondy D R 1965 Great Lakes ice cover, winter 1964-65. US Army. Lake Survey District. Corps of Engineers. Research Report RR 5-1 